\title{
PERUBAHAN PENGGUNAAN MODALITAS INTENSIONAL DALAM BAHASA MELAYU DAN BAHASA INDONESIA
}

\author{
Ulfa Kurniasih \\ Universitas Indonesia, Jakarta, Indonesia \\ Posel : ulfakurniasih@gmail.com
}

\begin{abstract}
Modality is the means of the speaker for his involvement in the truth of his speech propositions. In the semantic level, modalities can appear in all languages with their respective expressions. Modalities according to Alwi (1992) consist of intentional modalities, epistemic modalities, deontic modalities, and dynamic modalities. This study aims to look at changes in use in the aspects of intentional modalities in Malay and Indonesian. The data taken is in the form of Malay texts Hikayat Hang Tuah (1700), Hikayat Indera Nata (1800), and Ronggeng Dukuh Paruk (1982)..
\end{abstract}

Keywords: Modalities; Malay; Indonesian

Abstrak : Modalitas merupakan sikap pembicara atas keterlibatannya terhadap kebenaran proposisi tuturannya.Dalam tataran semantik, modalitas dapat muncul pada semua bahasa dengan bentukan pengungkapnya masing-masing.Modalitas menurut Alwi (1992) terdiri atas modalitas intensional, modalitas epistemik, modalitas deontik, dan modalitas dinamik.Penelitian ini bertujuan untuk melihat perubahan penggunaan pada aspek modalitas intensional dalam bahasa Melayu dan bahasa Indonesia.Data yang diambil berupa naskah Melayu Hikayat Hang Tuah (1700), Hikayat Indera Nata (1800), dan Ronggeng Dukuh Paruk (1982).

Kata Kunci : modalitas, bahasa melayu, bahasa indonesia 


\section{Pendahuluan}

Modalitas merupakan sikap pembicara terhadap peristiwa tuturan yang sekaligus juga merupakan ciri universalisme bahasa. Pandangan Halliday (1985) mengenai fungsi interpersonal bahasa yakni bahasa digunakan untuk menyatakan sikap pembicara sehubungan dengan peristiwa nonaktual yang diungkapkannya. Dalam menyatakan sikap nonaktual, penutur bahasa dihadapkan pada pilihan sifat unsur internal terhadap waktu pada peristiwa yang berlangsung. Seorang ahli yang pertama kali menaruh minat pada modalitas ialah Aristoteles.

Aristoteles menggunakan sudut pandang logika modal (modal logic) dengan menyebutkan adanya faktor keperluan (necessity), kemungkinan (possibility), dan ketakmungkinan (impossibility) sebagai permasalahan modalitas. Di dalam bahasa Inggris, pengungkap modalitas yang sering kita temukan seperti can, could, may, might, must, have to, had to, will dll.yang dalam bahasa Indonesia dikenal dengan bisa, dapat, boleh, harus, dll secara umum banyak ditemukan pembahasaannya dari segi gramatikal, sedang secara semantik kurang begitu mendalam.

Djadjasudarma

mengemukakan bahwa modalitas merupakan istilah linguistik untuk mengklasifikasi pernyataan menurut logika, yang menyuguhkan, mengingkari, memungkinan, mengharuskan, dan sebagainya. Modalitas bahasa Indonesia menurut Alwi (1992:26) dapat dibagi menjadi empat kelompok, yaitu modalitas intensional, yang mengungkapkan makna 'keinginan', 'harapan', 'ajakan', 'pembiaran', serta'permintaan'; modalitas epistemik, yang berhubungan dengan pengetahuan atau apa yang diketahui; modalitas deontik, yang berhubungan dengan 'izin' dan 'perintah'; modalitas dinamik, yang mengungkapkan makna kemampuan". Dalam hal ini, modalitas merupakan salah satu unsur penting dalam setiap bahasa.
Modalitas dipakai untuk menyatakan bagaimana cara menanggapi suatu tindakan, keadaan, dan kejadian yang sedang dihadapinya dengan menggunakan bahasa sebagai alatnya. Pembahasan akan difokuskan pada faktor internal yang terjadi di dalam bahasa Melayu tanpa dikaitkan dengan pengaruh dari bahasa lain.

Penelitian ini akan berfokus pada modalitas intensional menurut Hasan Alwi dengan analisis pada kata ingin, mau, hendak, dan akan pada naskah-naskah hikayat tahun 1700an (Hikayat Hang Tuah), 1800an (Hikayat Indera Nata), serta sastra Indonesia 1982 (Ronggeng Dukuh Paruk) dan bagaimana struktur sintaksis pada modalitas intensional yang digunakan dari abad 18 hingga abad 20 awal. Selain itu, penulis juga menggunakan teori perubahan makna oleh Keraf (2001). Penelitian singkat ini melihat bentuk perubahan apa yang terjadi pada kata ingin, mau, hendak, dan akan pada tiap abadnya. Sehingga ada banyak bentukan analisis yang merujuk pada bentukan analisis bahasa Indonesia yang dilakukan Alwi pada tahun 1990.

Makna yang berubah secara diakronis dapat dikelompokkan menjadi beberapa jenis perubahan. Gorys Keraf (2001) menjelaskan jenis perubahan sebagai berikut.

a. Meluas

Perubahan makna kata yang meluas terjadi ketika kata yang pada mulanya mengandung makna yang khusus, tetapi kemudian berubah menjadi lebih luas sehingga melingkupi sebuah kelas makna yang lebih umum. Contoh kata yang mengalami perluasan makna adalah putra dan putri. Dulu, dua kata ini digunakan untuk menyebut anak-anak raja, tetapi sekarang digunakan untuk laki-laki dan perempuan dari semua kalangan.

b. Menyempit

Penyempitan makna kata terjadi ketika makna sebuah kata yang awalnya memiliki cakupan makna yang luas kemudian berubah menjadi lebih khusus. Keraf (2001) 
Volume 1, Nomor 1, Januari 2019

ISSN 2655-3031 (P)

ISSN 2655-7851 (O)

menyebutkan contoh kata yang mengalami penyempitan di antaranya adalah kata pala dan pendeta. Kata pala awalnya berarti 'buah' secara keseluruhan, tetapi sekarang hanya ditujukan untuk menyebut satu buah saja. Kata pendeta tadinya bermakna 'orang yang berilmu' tetapi sekarang hanya digunakan untuk 'guru agama tertentu'.

c. Ameliorasi

Perubahan makna ameliorasi terjadi ketika makna yang baru dirasa lebih halus, tinggi, atau santun dibandingkan dengan makna sebelumnya. Kata wanita lebih tinggi dibandingkan dengan kata perempuan. Kata pria dirasa lebih tinggi dibandingkan dengan kata laki-laki.

d. Peyorasi

Peyorasi adalah kebalikan dari ameliorasi, yaitu perubahan makna terjadi ketika makna yang baru dirasa lebih rendah atau kasar dibandingkan dengan makna sebelumnya. Contohnya adalah kata bini. Dulu, kata ini dianggap memiliki makna yang tinggi, tetapi sekarang kata bini dirasakan sebagai kata yang kasar. Begitu pula dengan kata kaki tangan. Dulu (sekarang masih digunakan di Malaysia), kata ini memiliki arti yang baik, yaitu 'pembantu'. Namun, sekarang arti kata ini sudah bergeser menjadi makna yang tidak baik.

\section{e. Metafora}

Metafora adalah perubahan makna karena persamaan sifat di antara dua objek. Metafora disebut juga sebagai makna kiasan (figurative meaning). Perubahan makna ini merupakan pengalihan semantik berdasarkan kemiripan persepsi makna. Kata puteri malam yang berarti 'bulan' dan pulau yang berarti 'empu laut' merupakan kata-kata yang dibentuk berdasarkan metafora.

\section{f. Metonimi}

Metonimi terjadi karena hubungan yang erat antara kata-kata yang terlibat dalam suatu lingkaran makna yang sama dan dapat diklasifikasikan menurut tempat atau waktu, hubungan isi dan bunyi, serta hubungan sebab akibat. Kata kota tadinya bermakna 'susunan batu yang dibuat mengelilingi pemukiman'.
Sekarang, tempat pemukiman itu tetap disebut kotawalaupun susunan batunya sudah tidak ada.

\section{Metode Penelitian}

Penelitian ini akan melihat bentuk perubahan modalitas intensional pada sastra Melayu dan sastra Indonesia dari tahun 1700 hingga 1900an. Dalam penelitian ini, penulis menggunakan data tertulis yang diperoleh dari Malay Concordance Project serta dokumentasi tulisan naskah karya sastra. Data berupa naskah Hikayat Hang Tuah tahun 1700, Hikayat Negeri Indera Nata tahun 1800, dan novel Ronggeng Dukuh Parak tahun 1982.

Data dikumpulkan dengan menggunakan metode sampel dengan teknik pengambilan sampel secara acak. Data yang telah dikumpulkan kemudian dikelompokkan berdasarkan kategorisasinya untuk kemudian dikelompokkan berdasarkan kadar modalitasnya. Pada akhirnya penulis dapat melihat kecenderungan perubahan penggunaan modalitas yang terjadi dalam rentang waktu tiga abad tersebut. Ketiga data tersebut kemudian ditelusuri penggunaannya melalui Malay Concordance Project (pada naskah Melayu 1700 dan 1800) dan perangkat lunak antconc (pada naskah 1982).

Penggarapan sumber data secara keseluruhan tidak dapat penulis lakukan dalam penulisan ini. Oleh karena itu, penulis membatasi data yang digunakan sebagai sampel. Data tersebut diharapkan dapat mewakili data secara keseluruhan yang ada. Selanjutnya, penulis mengumpulkan data berupa modalitas intensional dari tiap-tiap abad dalam karya sastra yang telah ditetapkan sebagai sumber data. Untuk memudahkan penulisan, data-data ditulis menggunakan ejaan bahasa Indonesia. Penulisan singkatan ditulis sesuai dengan singkatan dari judul karya sastra. Tuah yang berarti Hikayat Hang Tuah (1700), Inata yang berarti Hikayat 
Volume 1, Nomor 1, Januari 2019

ISSN 2655-3031 (P)

ISSN 2655-7851 (O)

Indera Nata (1800), dan Rdp yang berarti Ronggeng Dukuh Paruk (1982).

\section{Hasil dan Pembahasan}

Alwi (1992) mengungkapkan bahwa secara umum dapat dikatakan bahwa ingin, mau, hendak, dan akan mengungkapkan makna yang dapat digolongkan sebagai 'keinginan' meskipun memiliki makna leksikal yang berbeda-beda, 'keinginan' untuk ingin dan 'kemauan' atau 'maksud' untuk mau, hendak, dan akan. Tinjauan berdasarkan makna leksikal tidaklah menggambarkan gradasi makna 'keinginan' yang diungkapkan oleh keempat kata tersebut. Oleh karena itu, 'keinginan yang kuat' yang dinyatakan oleh ingin perlu dibedakan dari 'keinginan yang lemah' yang dinyatakan oleh mau, hendak, atau akan. Berikut tabel kadar pengungkap modalitas menurut Alwi.

Tabel 1. Kadar Pengungkap Modalitas

\begin{tabular}{|c|l|c|c|c|}
\hline N & Pengung & \multicolumn{3}{|c|}{ Kadar } \\
\cline { 3 - 5 } & $\begin{array}{c}\text { kap } \\
\text { Modalita } \\
\text { s }\end{array}$ & $\begin{array}{c}\text { keingina } \\
\text { n' }\end{array}$ & $\begin{array}{c}\text { 'kemaua } \\
\text { n' atau } \\
\text { 'maksud } \\
\text { ' }\end{array}$ & $\begin{array}{c}\text { 'keakan } \\
\text { an' }\end{array}$ \\
\hline 1. & ingin & + & + & - \\
\hline 2. & mau & + & + & + \\
\hline 3. & hendak & - & + & + \\
\hline 4. & akan & - & + & + \\
\hline
\end{tabular}

\section{Kadar 'keinginan'}

Alwi mengatakan bahwa hanya 'ingin' yang dapat menyatakan kadar keinginan. Akibatnya, ingin tidak dapat disubstitusikan dengan 'mau', 'hendak', ataupun 'akan'. Namun, pada data ditemukan kadar keinginan yang tidak hanya terdapat pada kata ingin namun juga pada kata hendak. Hal itu tergambarkan pada contoh berikut.

(1) INata 178:2... Maka kata tuan puteri itu, "Wah kakanda, marilah kita pergi bermain-main di hutan negeri ini kerana beta ini sangat ingin makan kijang dan menjangan."

(2) INata 52:29 Setelah sudah sekalian rajaraja itu mesyuarat maka ia pun belayarlah masing-masing menuju negeri Rom siang malam tiada berhenti lagi kerana sangat ia hendak bertemu akan anaknya itu.

(3) Tuah 86:4...... dilihat oleh Bendahara dan Bentara raja sangat hendak melepaskan ke benua Keling itu maka Bendahara dan Bentara pun ..

Pada data ditemukan bahwa kadar 'keinginan' mengalami perluasan pada tahun 1700 dan 1800 yang tidak hanya ditandai dengan kata ingin namun, juga ditandai dengan kata hendak. Perluasan yang dimaksud ialah kadar 'keinginan' pada mulanya hanya terdapat pada kata yang khusus, yakni kata ingin tetapi ternyata pada data ditemukan bahwa kadar 'keinginan' terdapat pada kata hendak. Sedangkan pada tahun 1900, kadar 'keinginan' tidak dapat disubstitusikan dengan hendak.

Pada 'keinginan yang kuat', yang ditonjolkan adalah faktor 'keadaan' sedangkan pada 'keinginan yang lemah', faktor yang menentukan adalah faktor 'peluang'. Contoh kasus yang memperlihatkan faktor keadaan pada peristiwa nonaktual terlihat pada Srintil sebagai gadis berusia sebelas tahun yang tibatiba menjadi pusat perhatian banyak orang di kampungnya. Untuk pertama kalinya Srintil, gadis cilik yang cantik, didandani seperti seorang ronggeng dewasa. Selain itu, telah dua belas tahun sejak kematian ronggeng Dukuh Paruk yang terakhir, Dukuh Paruk bisu, tanpa suara calung. Rakyat rindu akan ronggeng.

(4) Rdp: 11 "Tak kusangka Srintil bisa menari sebagus itu," katanya. "Kalau boleh aku ingin menggendongnya, membuainya sampai dia lelap di pangkuanku." 
Volume 1, Nomor 1, Januari 2019

ISSN 2655-3031 (P)

ISSN 2655-7851 (O)

Pada kalimat (4) di atas, kata ingin menyatakan pada saat aktualisasi tuturan mengisyaratkan bahwa adanya 'keinginan yang kuat' yang memiliki kadar 'keinginan'dengan adanya keadaan-keadaan nonaktual yang mendukung.

(5) Rdp:10... Kita yang tua-tua di pedukuhan ini tak ingin mati sebelummelihat Dukuh Paruk kembali seperti aslinya dulu.

(6) Rdp:16... Serangga kotor ini mempunyaicara yang aneh bila hendak membawa tinja ke liangnya.

Kata ingin pada (5) tidak bisa disubstitusikan pada kata hendak (6). Karena kadar yang terdapat pada dua contoh data karya sastar tahun 1982 di atas berbeda. Contoh data di atas sesuai dengan rujukan Alwi bahwa hanya kata ingin yang menunjukkan kadar 'keinginan' pada abad 20. Sehingga dapatlah dikatakan bahwa kadar 'keinginan' tidak hanya terdapat pada kata ingin saja pada tahun 1700 dan 1800, namun dapat digunakan pada kata hendak(2) dan (3) jika kata hendak ini diawali dengan kata sifat sangat.

\section{Kadar 'kemauan' dan 'maksud'}

Pada tabel di atas telah digambarkan bahwa mau, hendak, dan akan dapat memiliki kadar 'kemauan' atau 'maksud'. Hal tersebut dapat dicontohkan pada data berikut.

(7) Rdp: 104 ... "Tidak demikian, Pak. Aku hanya merasa sangsi apakah aku dapat memenuhi syarat untuk memikul tugas yang akan kuterima itu,"

(8) Rdp: 109 ... Aku akan membayar dendam.

Data (7) pada kata akanmenyatakan 'kemauan' sedangkan pada (8) menyatakan 'maksud'. Pada bagian ini, yang menjadi bahan perhatian penulis ialah ketumpangtindihan kadar 'kemauan' dan 'maksud' pada data Hikayat Melayu. Hal tersebut terdapat pada data berikut.
(9) Tuah 204:14.... Hendak membunuh kita pula, si hancur lebur ini! Pada bicaranya, kita mauakan Tun Tuah itu? Sedang raja Melaka itu tuanku hendak akan kita, kita tiada mau; ini pula hambanya. Seperkara pula, kita pun sudah bertunangan; bukan ia tiada tahu.

Pada data (9), terdapat penggunaan kata mauakan dan hendak akan yang digunakan secara berdampingan dalam satu kalimat. Penggunaan secara berdampingan ini tidak ditemukan baik pada data tahun 1700 maupun pada data tahun 1900. Kata hendak akan dalam data di atas memiliki kadar 'kemauan' sedangkan kata mau akan tidak lagi berbicara mengenai kadar 'kemauan' namun secara semantis maknanya telah mengalami perluasan. Kata mau jika disandingkan dengan kata akanpada data (9) di atas bermakna kepadaatau pada.

Sehingga dapatlah dikatakan bahwa kadar 'kemauan' dan 'maksud' dengan kata mau, hendak, dan akan terdapat pada tiap-tiap tahun dari 1700 dan 1800. Namun, hanya pada tahun 1800 saja kata akan yang jika bersanding dengan kata penunjuk modalitas lainnya dari kadar 'kemauan' dan 'maksud' memiliki makna ganda yang bergantung pada konteks kalimatnya. Kata tersebut dapat berarti memiliki kadar 'kemauan' saja atau bisa jadi kata tersebut telah memiliki makna semantis yang baru. Sedang jika kata tersebut berdiri sendiri, maka kata tersebut dapat memiliki kadar 'kemauan' dan/atau kadar 'maksud'.

\section{Kadar 'keakanan'}

Pemakaian mau, hendak, dan akan sebagai pengungkap kadar keakanan dapat dibandingkan dengan pemakaian will dan shall dalam bahasa Inggris yang juga digolongkan sebagai penanda kala (future tense) dan juga dapat digolongkan sebagai verba pewatas pengungkap modalitas. Pemaparan mengenai will dan shall tersebut mengisyaratkan bahwa 'keakanan' sebagai istilah semantis perlu dibedakan dari 'kala 
Volume 1, Nomor 1, Januari 2019

ISSN 2655-3031 (P)

ISSN 2655-7851 (O)

akan' sebagai istilah gramatikal. 'Keakanan' dalam bahasa Indonesia tampak pada mau, hendak, dan akan karena pemakaian ketiga kata tersebut digunakan dalam mempertimbangkan keadaan pada saat peristira tuturan.

(10) INata 3:29 Kalakian maka Raja Muda pun tersenyum menengar kata tuan puteri itu seraya berpantun: | Jika tuan tanam melati, Keladi di dalam benua*; Jika mau tuan diambil isteri, Biarlah adinda kakanda bawa. |

(11) Tuah 97:25 "Jika demikian, segeralah mamak Bendahara mengarang surat dan bingkis akan saudara kita raja Inderapura. Dalam tiga hari ini juga mau pergi." Maka sembah Bendahara, "Daulat Tuanku Syah Alam."

(12) Rdp : 32 .."Aku mau mandi sekarang, Rasus. Sebaiknya engkau pulang. Kalau mau kau bisa menonton nanti malam. Aku akan menari lagi."

Kadar 'keakanan' ditunjukkan pada data (12) sedangkan pada data (10)-(11) kata mau memiliki makna secara semantis yang tidak hanya menunjukkan kadar 'keakanan' namun dapat juga menunjukkan 'kesediaan' (10). Pada data (11), kadar 'keakanan' ditunjukkan oleh mau sedang kata akan tidak bermakna 'keakanan'. Perubahan fungsi kadar 'keakanan' pada data (11) oleh kata akan terjadi secara semantis yang disebabkan oleh kehadiran nomina sehingga kata akan merujuk pada makna kepada. Secara sintaksis, perubahan makna yang terjadi pada tahun 1700 terjadi akibat adanya pola sebagai berikut.

(a) $\frac{\text { Mamak Bendahara mengarang surat dan }}{\mathrm{S}}$ $\underline{\text { bingkis akan saudara kita raja Inderapura }}$ $\mathrm{O}$

(b) Segeralah mamak Bendahara menulis $\mathrm{S}$ $\frac{\text { surat dan mengirimnyakepada saudara }}{\mathrm{P}} \underline{\mathrm{O}}$.
Kata akan dalam kalimat di atas tidak lagi berdiri sebagai modalitas intensional melainkan berfungsi sebagai preposisi penunjuk tujuan. Sementara dalam naskah sastra Indonesia tahun 1900 kata akan digunakan sebagai modalitas, sedangkan preposisi penunjuk tujuan yang lebih banyak digunakan ialah kata kepada.

\section{Simpulan}

Berdasarkan pembahasan di atas terhadap karya sastra Melayu dan sastra Indonesia, terjadi perkembangan penggunaan kadar modalitas yang cukup menarik. Jika kita mengacu pada perubahan makna menurut Gorys Keraf (2001), penggunaan modalitas dari abad 18 hingga 19 awal ternyata mengalami perubahan. Perubahan tersebut bisa jadi meluas, namun di sisi yang lain menyempit. Aspek modalitas intensional dengan kadar 'keinginan' mengalami perluasan pada tahun 1700 dan 1800 yang tidak hanya ditandai dengan kata ingin namun juga ditandai dengan kata hendak. Perluasan yang dimaksud ialah kadar 'keinginan' yang pada mulanya hanya terdapat pada kata yang khusus, yakni kata ingin tetapi dapat ditemukan juga pada kata hendak jika kata tersebut didahului oleh adjektiva sangat.

Selain itu, terdapat modalitas yang digunakan secara berdampingan pada tahun 1800 yang tidak ditemukan pada data tahun 1700 maupun data tahun 1900. Modalitas yang dimaksud ialah katahendak akanyang berdasarkan hasil analisis memiliki kadar 'kemauan' sedangkan kata mau akan tidak lagi berbicara mengenai kadar 'kemauan' namun secara semantis maknanya telah mengalami perluasan menjadi rujukan pada nomina.

Secara keseluruhan, penulis melihat bahwa terjadi kecenderungan perubahan modalitas yang digunakan dari abad 18 hingga 19 awal. Pada data ditemukan bahwa modalitas tahun 1800 memiliki kekayaan penggunaan baik dalam hal penggunaan modalitas yang berdampingan maupun dalam hal perubahan makna modalitas secara 
Volume 1, Nomor 1, Januari 2019

ISSN 2655-3031 (P)

ISSN 2655-7851 (O)

semantis. Namun demikian, apa yang penulis analisis dan sampaikan di atas masih jauh dari data yang sifatnya dapat merepresentasikan perubahan modalitas intensional yang terjadi pada tiap-tiap abad dari abad 18 hingga abad 19 awal. Oleh karena itu, penelitian di atas masih berpeluang untuk dikaji lebih lanjut sehingga dapatlah dilihat secara jelas mengenai perubahan modalitas secara gramatikal, semantis, maupun sintaksisnya.

\section{Daftar Pustaka}

Alwi, Hassan. 1992. Modalitas Dalam Bahasa Indonesia.Seri ILDEP Yogyakarta. Penerbit Kanisius.

Cruse, D. A. $1986 . \quad$ Lexical Semantics.Cambridge University Press.

Halliday, M.A.K. 1985. An Introduction to Functional Grammar. London: Edward Arnold.

Keraf, Gorys. 2001. Diksi dan Gaya Bahasa. Jakarta: PT Gramedia Pustaka Umum.

Palmer, F.R. 1979. Modality and the English Modal. London: Longman. 